\title{
PHYTOCHEMICAL AND BIOLOGICAL INVESTIGATION OF RUSSELIA EQUISTIFORMIS (SCROPHELARIACEAE) CULTIVATED IN EGYPT
}

\author{
Atef. A. El Hela, ${ }^{*}$ Nevein, M. Abdel Hady "Magda, T. Ibrahim, \\ and "Salwa, A. Abu Elwafa \\ Department of Pharmacognosy, Faculty of Pharmacy, Al-Azhar University "Boys", Cairo. \\ "Department of Pharmacognosy, Faculty of Pharmacy, Al-Azhar University "Girls".
}

\begin{abstract}
From the methanol extract of Russelia equisetiformis (Scrophelariaceae) cultivated in Egypt ten phenolic compounds were isolated and identified as gallic acid, methylgallate, vicenin $\mathrm{II}$, chrysoeriol-7-O-ß-D- ${ }^{4} \mathrm{C}_{1}$ glucopyranoside, luteolin 7-O-glucoside, luteolin-7-O- $\beta-\mathrm{D}-{ }^{4} \mathrm{C}_{1}{ }^{-}$ arabinoside, quercetrin, apigenin, luteolin and acetoside. The structures of the isolated compounds were elucidated on the basis chromatographic and spectroscopic data (UV, IR and NMR) where all compounds were isolated for the first time except acetoside. The biological investigation antidepressant and hepatoprotective effect of different extracts of Russelia equisetiformis was carried out, concerning the antidepressant property the $n$-butanol was the most active, followed by aqueous and crude phenylethanoids extract respectively and Fluoxetine as reference standard, while the hydro-alcohol extract exhibited significant hepatoprotective effect against carbon tetrachloride injured liver cells.
\end{abstract}

Keywords: Russelia equisetiformis, phenolic compounds, antidepressant, Fluoxetine, hepatoprotective, carbon tetrachloride.

\section{INTRODUCTION:}

Higher plants are important sources of secondary metabolites those having therapeutic and pharmaceutical applications, these metabolites; despite of being used as primitive drugs, have been a part of human health for many centuries across all cultures. The World Health Organization (WHO) has estimated that more than $80 \%$ of the world's population in developing countries depends primarily on herbal medicine for basic healthcare needs, (Vines, 2004).

Genus Russelia belonging to family Scrophelariaceae refers the name honors to the Scottish naturalist Alexander Russell (1715-1768); its members grow worldwide and are characterized by being mildly drought resistant, they are common garden plants well recognized by their brilliant red flowers that are shaped like slender vases and commonly known as Firecracker plants or Coral blows, (Awe et al., 2004b and Quattrocchi, 2000).

Russelia equisetiformis (Schlecht\& Chan) perennial evergreen shrubs cultivated in Egypt for ornamental and slope protection purposes (Yeager and Gilman, 1991). It is a medicinal plant that reported to have anti-inflammatory, analgesic, central nervous system depressant, free radical scavenging, hair growth promoting and membrane stabilizing properties (Awe et al, 2010, Awe and Makinde, 2009, Awe et al, 2009, Kolawole et al, 2007, Awe et al, 2006 and Awe et al, 2004b), in addition to its uses by traditional healers in Nigeria to treat malaria, cancer as well as inflammatory diseases (Awe and Makinde, 2009).

Concerning phytochemical composition, some reported data revealed the existence of triterpenes, phenolic compounds and flavonoids (Awe et al., 2009; Awe et al., 2004b and Wollenweber et al., 2000), the triterpenes isolated were of lupane type (Burns et al, 2000 and Abu-Mustafa $\boldsymbol{e t}$ al, 1997), the total phenolic content was previously estimated (El Hela $\boldsymbol{e t}$ al., 2011 and Johnson et al, 2011) while the HPLC investigation of its methanol extract revealed the 
existence of several flavonoids i.e. 6, 8-diglucosylapigenin, 6-arabinosyl-8-glucosyl apigenin, orientin, vitexin, luteolin 7-O-glucuronide, apigenin- $O$-glucuronide, apigenin and phenylethanoid glycosides as russectinol "verbascoside", russeliaoside and isoverbascoside (Johnson et al, 2011, Lin and Harnly 2008, Awe et al, 2008, Lin and Harnly 2007, Awe et al, 2008, Awe et al, 2004a and Burn et al, 2001).

This study was carried out as extension of previous one included pharmaco-gnostical studies of Russelia equisetiformis (EI Hela et al, 2011) targeting further investigation to isolate and identify of the phenolic constituents as well as study of antidepressant and hepatoprotective effects.

\section{EXPERIMENTAL 1- MATERIAL}

\section{1-1 Plant material:}

Russelia equisetiformis were collected from plants cultivated in El- Zohrya garden, Cairo, on April 2006, their identity was established by Professor Dr. Mohamed El-Sayed Tantawy, Professor of Botany, Faculty of Science, Ain Shams University and voucher specimens are kept in a herbarium in Pharmacognosy Department, Faculty of Pharmacy Al-Azhar University, Cairo, Egypt.

The plant material was air-dried, powdered and kept in tightly closed amber colored glass containers and protected from light at low temperature as possible.

\section{1-2 Material for investigation of phenolic constituents:}

\section{1-2.1 Material for chromatography:}

- Polyamide 6S (Riedel De Haen AG, Seelze, Hannover) for CC.

- Microcrystalline cellulose for CC (E. Merck)

- Silica gel-G for CC 70-230 meshes (E. Merck).

- Silica gel for TLC 60 meshes (E. Merck).

- Sephadex LH-20 for CC (Pharmacia, Uppsala, Sweden).

- Whatmann No.1 sheets for PC (Whatmann Ltd., Maidstone, Kent, and England).

1-2.2 Solvent systems:

$\mathbf{S}_{\mathbf{1}}$; $n$-Butanol: Acetic acid: Water (4:1:5 v/v), upper layer.

$\mathbf{S}_{\mathbf{2}}$; Acetic acid: Water $(15: 85 \mathrm{v} / \mathrm{v})$.

$\mathbf{S}_{\mathbf{3}} ; n$-Butanol: $2 \mathrm{M}$ ammonium hydroxide $(1: 1 \mathrm{v} / \mathrm{v})$ upper layer.

$\mathbf{S}_{\mathbf{4}}$; BPTW, Butanol: Pyridine: Toluene: Water (4:1:2:2 v/v).

$\mathbf{S}_{5}$; Chloroform: Methanol (90:10 v/v).

$\mathbf{S}_{\mathbf{6}}$; $n$-Butanol: Isopropyl alcohol: Water (4:1:5 v/v), upper layer.

$\mathbf{S}_{7}$; Chloroform: Methanol: Water $(80: 20: 2 \mathrm{v} / \mathrm{v})$.

$\mathbf{S}_{\mathbf{8}}$; Petroleum ether: Benzene: Ethyl acetate (75: 25: 0.5 v/v).

1-2.3 Spray reagents for PC and TLC:

- Ferric chloride for phenolic compounds, (Markham 1982).

- Aluminium chloride for flavonoids, (Stahl 1969).

- Aniline hydrogen phthalate for sugars, (Hiermann 1983).

- Diphenyl borinic acid ethanolamine complex (Naturstoff's spray reagent) for flavonoids, (Mabry et al, 1970). 


\section{1-2.4 Reagents for UV spectroscopic analysis of flavonoids (Matlok 1967):}

\section{1-2.5 Authentic reference material:}

1-2.5.1 Sugars: D-Glucose, D-galactose, D-arabinose, D-xylose, L-rhamnose, D-glucouronic and D-galacturonic acids (E. Merck, Darmstadt, Germany).

1-2.5.2 Flavonoids: Apigenin 7-O-glucoside, Apigenin 7-O-galactoside, Vitexin, Quercetin 3-Oglucoside, Quercetin 3-O - rutinoside, Luteolin-7-O -glucoside, Luteolin-7-O-galactoside, Luteolin7- $\boldsymbol{O}$-arabinoside and Quercetin.

Both sugars and flavonoids were kindly obtained from Pharmacognosy Department, Faculty of Pharmacy, Gedansk, Poland

\section{1-3 Material for biological studies:}

\section{1-3.1 Antidepressant effect:}

\section{1-3.1.1 Animals:}

Adult albino mice of both sexes weighing 20-25g were used; they were kept in quiet place under conventional laboratory conditions and were allowed free access to water and food throughout the period of investigation.

\section{1-3.1.2 Tested material:}

- Extracts; $70 \%$ methanol, $n$-butanol and aqueous extracts.

- Authentic material; Fluoxetine. - Tween 80.

\section{1-3.2 Hepatoprotective effect:}

\section{1-3.2.1 Animals:}

Adult albino male and female albino rats weighing 100-120 g were used; they were kept in quiet place under conventional laboratory conditions and were allowed free access to water and food throughout the period of investigation.

\section{1-3.2.2 Tested material and reagents:}

- Extracts; $70 \%$ methanol extract.

- Carbon tetrachloride.

- Transaminases kits; All reagents were supplied as pre-made kits from Stanbio Company USA, they were as reagents for determination of AST, ALT, ALP, Gamma-GT, total bilirubin, SOD, CAT and ascorbic acid (vitamin C).

\section{2- APPARATUS}

- Rotatory evaporator (BUCHI Rotavapor® R-210/R-215, Germany).

- Chromatographic plates: glass plates $20 \times 20$ and $20 \times 10 \mathrm{~cm}$.

- Rectangular glass tanks $50 \times 56 \times 20 \mathrm{~cm}$ was used for PC and $24 \times 24 \times 10 \mathrm{~cm}$ for TLC.

- Glass columns for chromatography $130 \mathrm{~cm} \times 3.5 \mathrm{~cm}, 100 \mathrm{~cm} \times 3 \mathrm{~cm}, 30 \mathrm{~cm} \times 1.5 \mathrm{~cm}$ and $50 \mathrm{~cm}$ $\times 1 \mathrm{~cm}$.

- Glass Buchner funnel with fritted disc (ASTM, 10-15 $\mu$ OR 10-20 $\mu$ ) for VLC.

- UV Lamp ( 254/365 nm.), dosage Heidelberg - Germany- Duo - UV- source for thin layer and column chromatography.

- NMR Spectrometer; NMR analyses were measured on a Varian Mercury 300, 500, 600 (300 \& $75 \mathrm{MHz}$ for ${ }^{1} \mathrm{H}$ for ${ }^{13} \mathrm{C}$ ). All samples have been prepared in suitable deutrated solvents with TMS as internal reference.

- Mass Spectrometer: Varian Mat 711, Finnigan SSQ 7000 and OMM 7070 E.

- Electrospray (ESI) - MS (positive and negative ion acquisition mode) was carried out on a TSQ700 triple quadrupole instrument (Finnigan, San Jose, CA, USA) by using the Finnigan 
electrospray atmospheric pressure chemical ionization source. Samples dissolved in $10 \mu \mathrm{l}$ of $50 \%$ methanol were injected at a flow-rate of $0.3 \mu \mathrm{l} / \mathrm{min}$ using $50 \%$ methanol as carrier. The electrospray positive voltage was set at $+4.5 \mathrm{kv}$ or at $-4.2 \mathrm{kv}$ for negative ions and nitrogen (30 psi) was used as sheath gas. Scans were performed from $m / z, 50$ to $m / z, 2000$ in $2 \mathrm{~s}$, and the spectra acquired were the average of a 2 min period. The multiplier voltage was set at $1200 \mathrm{~V}$.

- UV/VIS spectrophotometer Shimadzu UV 240 (P/N 240-58000) was used for recording UV spectra and measuring absorbance in UV range.

- Swimming pool (Glass cylinder $25 \mathrm{~cm}$ high, $10 \mathrm{~cm}$ diameter) containing fresh water to a height of $10 \mathrm{~cm}$ maintained at a temperature of $23{ }^{\circ} \mathrm{C}-25^{\circ} \mathrm{C}$ ).

-Centrifuge (LPHC 2514 High Speed Centrifuge, Liaoyang Pharma Machinery).

- Spectrophotometer for biological studies; Beckman Du 460.

\section{3- GENERAL PROCEDURES:}

3-1Extraction, isolation, fractionation; $1.5 \mathrm{~kg}$ of air-dried plant was exhaustively extracted with methanol, after stripping off the solvent under reduced pressure and low temperature $\left(\sim 50{ }^{\circ} \mathrm{C}\right)$, the brownish sticky defatted residue was suspended in water and re-extracted with $n$-butanol to yield the $n$-butanol soluble fraction which was concentrated to dryness under vacuum to give $250 \mathrm{~g}$ yield, an aliquot of the residue $200 \mathrm{~g}$ was chromatographed on a polyamide column; elution was started with water followed by water/methanol mixture and decreasing polarities up to pure methanol, $100 \mathrm{ml}$ fractions were collected, subjected to TLC and PC examination aided by VIS, UV, spray reagents visualization, similar fractions were collected together. Fractions were subjected to successive CC on sephadex LH-20, silica gel, and/or microcrystalline cellulose with different solvent systems, fractionated and subsequently purified to yield nine sub-fractions, they are:

Fraction-A which when concentrated and precipitated with ethanol from water and subjected to two dimensional paper chromatography (TDPC) revealed the presence of one major phenolic compound, it was purified by sephadex LH-20 column using water/ethanol mixture to yield $\mathbf{3 0} \mathbf{~ m g}$ of compound 1 which was then crystallized from water.

Fraction-B which when concentrated and precipitated with ethanol from water and subjected to two dimensional paper chromatography (TDPC) revealed the presence of one major phenolic compound, it was purified by sephadex LH-20 column using water/ethanol mixture to yield $\mathbf{2 5} \mathbf{~ m g}$ of compound $\mathbf{2}$ which was then crystallized from ethanol.

Fraction-C which when concentrated and subjected PC revealed the presence of one major and few minor phenylethanoid compounds, then it was subjected to microcrystalline cellulose column using $30 \%$ ethanol eluent followed by extraction by ethyl acetate through liquid-liquid portion from water, the residue obtained was fractionated by repeated column chromatography on Sephadex LH-20, and eluted with methanol to give $\mathbf{5 0} \mathbf{~ m g}$ of compound $\mathbf{3}$.

Fraction-D $35 \mathrm{~g}$ which was subjected to PC using solvent systems $\mathrm{S}_{1}$ and $\mathrm{S}_{2}$ revealed the presence of one major spot of flavonoid nature and few minor spots, then fraction was subjected to repeated CC on sephadex LH-20 and eluted with methanol, then increase polarity with water to give $\mathbf{4 0} \mathbf{~ m g}$ of compound 4 .

Fraction-E was subjected to repeated CC on sephadex LH-20 and eluted with methanol, then increase polarity with water and when subjected to PC using solvent systems $S_{1}$ and $S_{2}$ three deep purple colour spots under UV light developed which changed to yellow using ammonia vapor is gained which also showed greenish blue with ferric chloride and greenish yellow with Naturstoff's spray reagents, this behavior indicates of flavonoid glycoside nature of compounds $\mathbf{5 , 6}$ and $\mathbf{7}$. 
Fraction- $\mathbf{F}$ was subjected to consecutive columns sephadex LH-20 using $\mathrm{S}_{6}$ as eluent and sephadex LH-20 using ethyl alcohol to afford pure sample which when subjected to PC using solvent systems $S_{1}$ and $S_{2}$ dark purple fluorescent spots under UV light which change to dull yellow using ammonia vapor is gained and also showed greenish and greenish yellow with Naturstoff's spray reagents, this behavior indicates of flavonoid glycoside nature of $\mathbf{8}$.

Fraction- $\mathbf{G}$ and Fraction -H were subjected PC using solvent systems $S_{1}$ and $S_{2}$ and yielded several minor spots.

Fraction-I was soluble in mixture of chloroform and methanol, insoluble in pure chloroform which was subjected to repeated CC on silica gel LH-20 and eluted with methanol, then decrease polarity with chloroform and when subjected to PC using solvent systems $S_{7}$ and $S_{8}$ three deep purple colour spots under UV light developed which changed to yellow using ammonia vapor is gained which also showed greenish blue with ferric chloride and greenish yellow with Naturstoff's spray reagents, this behavior indicates of flavonoid aglycone nature of compounds 9,10 and 11.

The rest of the isolated minor fractions were kept for further investigation.

\section{3-2 techniques for investigation of phenolic content:}

\section{3-2.1 Chromatographic methods:}

3-2.1.1 Paper chromatography (Stahl 1969); Whatmann No. 1 paper sheets for analytical PC were used, the chromatograms, spotted with the fractions under investigation, and allowed to equilibrate with the atmosphere of the jar and then developed using descending technique and suitable solvent system, or by two dimensional technique using $S_{1}$ for first run and $S_{2}$ for the second. The chroma-tograms were air dried, the spots were visualized under UV-light before and after spraying with the suitable reagent and heating in oven for $5 \mathrm{~min}$ at $105{ }^{\circ} \mathrm{C}$ in case of Naturstoff's, aluminum chloride and aniline hydrogen phthalate spray reagents.

3-2.1.2 Thin layer chromatography (Stahl 1969); Precoated silica gel chroma-tographic plates $(20 \times 20 \mathrm{~cm}) 0.2 \mathrm{~mm}$ thickness were used for analytical separation and layers of $0.5-1 \mathrm{~mm}$ thickness were used in preparative separation.

3-2.1.3 Column chromatography (Harborne et al, 1975); Glass columns of different sizes were packed with polyamide, cellulose, sephadex LH-20 or silica gel were used, the solution of extract/fraction to be fractionated was applied on the top of the column, elution was then started with the eluent stated in each case.

Phenolic and flavonoid bands formed during the elution process were traced in both visible and long UV light; each fraction eluted from the column was then collected and dried under reduced pressure.

\section{3-2.1.4 Acid hydrolysis of glycosides (Harborne et al, 1975):}

3-2.1.4.1 Mild acid hydrolysis; Pure compounds to be hydrolyzed (3-5 mg) were treated with $0.1 \mathrm{~N} \mathrm{HC1}$ in $50 \%$ aqueous methanol for $60 \mathrm{~min}$. at $100{ }^{\circ} \mathrm{C}$, the produced mixture was traced every 10 minute intervals by $\mathrm{CoPC}$ to detect any intermediate or sugar that may be formed during the hydrolysis.

3-2.1.4.2 Complete acid hydrolysis; Pure compounds to be hydrolyzed (3-4 mg) were treated with $2 \mathrm{~N} \mathrm{HC} 1$ in $50 \%$ aqueous methanol for $2 \mathrm{hr}$ at $100{ }^{\circ} \mathrm{C}$, after evaporation of methanol cold aqueous mixture was exhaustively extracted with ethyl acetate in separating funnel, aglycones were identified in the ethyl acetate fraction by CoPC alongside authentic aglycones and/or using different spectroscopic analysis while the aqueous phase was neutralized with $5 \%$ sodium bicarbonate and used for investigation of the sugar moieties on CoPC against authentic samples using aniline hydrogen phthalate as a spray reagent. 


\section{3-3.3 Biological studies:}

3-3.3. 1 Determination of median lethal dose, LD50 (Kerber 1941); Methanol extract was suspended in distilled water using tween 80 and given orally to mice in graded doses; control group received the same volume of distilled water where the percentage of mortality was recorded $24 \mathrm{~h}$ later, results were analyzed statistically and $\mathrm{LD}_{50}$ was calculated.

\section{3-3.3.2 Methods for investigation of antidepressant effect:}

3-3.3.2.1 Experimental design and route of administration; Animals were divided into six groups, ten mice each, divided as follows; Group 1: normal mice received saline and served as normal control, Group 2: normal mice received Fluoxetine at dose level of $10 \mathrm{mg} / \mathrm{Kg}$, Group 3: normal mice received $n$ - butanol fraction at dose level of $300 \mathrm{mg} / \mathrm{Kg}$, Group 4: normal mice received crude fraction of total phenylethanoid glycosides at dose level of $300 \mathrm{mg} / \mathrm{Kg}$ and Group 5: normal mice received aqueous decoction at dose level of $300 \mathrm{mg} / \mathrm{Kg}$.

Behavioral test namely forced swimming test (FST) was performed which is the most widely used tool for assessing antidepressant activity pre-clinically. The widespread use of this model is largely a result of its ease of use, reliability and ability to detect broad spectrum of antidepressant agents (Borsini and Meli 1988).

Plant extracts were administered orally at dose levels of $300 \mathrm{mg} / \mathrm{Kg}$ (Kolawole and Wakeel 2006), they were suspended in $1 \%$ tween 80 / saline while Fluoxetine hydrochloride was used in a dose of $10 \mathrm{mg} / \mathrm{Kg}$.

3-3.3.2.2 Forced swimming test (Kolawole and Wakeel 2006, Duman 2004, Briner and Dodel , 1998 and Feighner 1999); FST was performed according to the method described by Porsolt $\boldsymbol{e t}$ al., (1977).

\section{3-3.3.3 Methods for investigation of hepatoprotective effect:}

3-3.3.3.1 Induction of liver disease and experimental design; 100 rats were injected with $\mathrm{CCl}_{4}$ (i.p.) diluted with paraffin oil (50\%v/v) for one month three times weekly at a dose of $300 \mu \mathrm{l} / 100 \mathrm{~g}$ b.wt. (Blonde $\boldsymbol{e t} \boldsymbol{a l}, \mathbf{1 9 9 4 )}$, animals remained alive were classified into three groups, twelve rats each, as follows; Group 1: received daily oral dose of methanol extract at dose level of 300 $\mathrm{mg} / \mathrm{Kg}$ in addition to food and water, Group 2: treated with $\mathrm{CCl}_{4}$ only and Group 3: control which left without any treatment, after two weeks, blood samples were collected for biochemical estimation, divided into two aliquots; the first received on EDTA in dry clean tubes for SOD, CAT and GSH in $\mathrm{RBC}_{\mathrm{S}}$, while the second aliquot was received in dry clean tubes and allowed to clot at $37{ }^{\circ} \mathrm{C}$ one h, then centrifuged at $3000 \mathrm{rpm}$ for $15 \mathrm{~min}$., serum was separated and divided into aliquots and vitamin $\mathrm{C}$ was measured at once, and other serum aliquots were stored at $-20{ }^{\circ} \mathrm{C}$ for one week during which the other biochemical parameters were done.

\section{3-3.3.3.2 Evaluation of liver functions:}

Liver functions were evaluated by measuring the following parameters:

- Quantitative determination of aspartate amino transferase (AST) in serum was performed according to Young 1975.

- Quantitative determination of alanine amino transferase (ALT) in serum was performed according to Tietz 1976.

- Quantitative determination of alkaline phosphatase (ALP) in serum was performed according to Kochmar and Moss 1976.

- Quantitative determination of gama-gt in serum was performed according to Szasa 1969.

- Quantitative determination of total bilirubin in serum was performed according to Doumas $\boldsymbol{e t}$ al, 1973.

- Quantitative determination of superoxide dismutase (SOD) in $\mathrm{RBC}_{\mathrm{S}}$ was performed according to Williams et al, 1983. 
- Quantitative determination of catalase (CAT) in $\mathrm{RBC}_{S}$ was performed according to Cohen 1970.

- Quantitative determination of ascorbic acid (vitamin C) in serum was performed according to

Denson and Bowers 1961.

\section{RESULTS AND DISCUSSION}

Russelia equisetiformis is a medicinal plant considered to have anti-inflammatory, analgesic and membrane stabilizing properties (Awe et al, 2009 and Awe et al, 2004a) where two phenylethanoid glycosides were identified as its main active constituents (Awe $\boldsymbol{e t} \boldsymbol{a l}, \mathbf{2 0 0 7}$ and Awe et al, 2004b) while other unidentified phenolic and/or flavonoid compounds were reported in its HPLC chromatogram and so, in this work we proceed in further investigation of such phenolic compounds as well as study of some biological effects.

The study achieved the isolation and characterization of the following compounds:

\section{Compound 1:}

Pale yellow needles having m.p. $252{ }^{\circ} \mathrm{C}$ which on PC investigation yielded one spot with $\mathrm{R}_{\mathrm{F}}$ value 0.56 and 0.79 in solvent systems $S_{1}$ and $S_{2}$ respectively, shine violet fluorescent under short UV light, blue colour with ferric chloride spray reagent indicating its phenolic in nature and was assumed from its UV spectrum in methanol at $\lambda$ max $272 \mathrm{~nm}$. The presence of hydroxyl and carboxylic functional groups and aromatic ring were indicated from the IR spectrum. Its molecular formula was concluded to be $\mathrm{C}_{7} \mathrm{H}_{6} \mathrm{O}_{5}$ from the molecular ion peaks at m/z 169 [M-H] - and 151 [M-H2O] - in the ESI-MS spectrum , ${ }^{1} \mathrm{H}-\mathrm{NMR}$ revealed the presence of one singlet in the aromatic region at $\delta 7.06$ integrating for two protons $(\mathrm{H}-2$ and $\mathrm{H}-6)$ indicating the presence of 1,3 , 4, 5-tetrasubstituted benzene ring.

From the above data and comparison with authentic sample, compound $\mathbf{1}$ was identified as gallic acid; (3, 4, 5,-trihydroxy-benzoic acid), figure; 1, (Harborne et al, 1982).

\section{Compound 2:}

Yellowish amorphous powder having m.p. $204{ }^{\circ} \mathrm{C}$ which on PC investigation yielded one spot with $R_{F}$ value 0.63 and 0.76 in solvent systems $S_{1}$ and $S_{2}$ respectively, shine violet fluorescent under short UV light, blue colour with ferric chloride spray reagent indicating its phenolic nature and was assumed from its UV spectrum (methanol) at $\lambda$ max $272 \mathrm{~nm}$. The presence of hydroxyl and methoxyl functional groups and aromatic ring were indicated from the IR spectrum. Its molecular formula was concluded to be $\mathrm{C}_{8} \mathrm{H}_{8} \mathrm{O}_{5}$ from the molecular ion peaks at m/z $183[\mathrm{M}-\mathrm{H}]-$ in the ESI-MS spectrum, ${ }^{1} \mathrm{H}-\mathrm{NMR}$ revealed the presence of one singlet in the aromatic region at $\delta$ 6.95 integrating for two protons ( $\mathrm{H}-2$ and $\mathrm{H}-6)$ indicating the presence of 1, 3, 4, 5-tetrasubstituted benzene ring and one singlet in the aliphatic region at $\delta 3.7$ corresponding to methyl group.

From the above data and comparison with authentic sample, compound $\mathbf{2}$ is identified as methyl gallate, figure; 1, (Harborne et al, 1982).

\section{Compound 3:}

Creamy white amorphous powder weighing $50 \mathrm{mg}$ gave positive Molisch's test which on PC investigation yielded one spot with $R_{f}$ value 0.75 in solvent system $S_{1}$ gave blue colour and deep greenish blue fluorescence with ferric chloride and Naturstoff's spray reagents respectively its phenylethanoid glycoside nature and was assumed from its UV spectrum (methanol) at $\lambda$ max 330, 285 and $220 \mathrm{~nm}$.

On complete acid hydrolysis, it gave caffeic acid which was identified by PC alongside with standard cinnamic acid derivatives as caffeic, ferulic, coumaric,..etc., using solvent systems $S_{1}$ and $S_{3}$, the chromatogram revealed the presence of caffeic acid having $R_{f}$ values 0.04 and 0.79 the two solvent system $S_{1}$ and $S_{3}$ respectively while sugars obtained were identified by PC using 
solvent systems $\mathrm{S}_{1}, \mathrm{~S}_{4}$ alongside with authentic sugars; visualization of sugars was carried out by spraying with aniline phthalate then heating at $110{ }^{\circ} \mathrm{C}$ for 15 minutes.

${ }^{1} \mathrm{H}-\mathrm{NMR}$ Spectrum showed two ABX coupling systems attributed to caffeoly moiety and 3,4 dihydroxy phenylethanoid aglycone, (Harborne et al., 1982) in addition to two signals at $\delta$ $4.5(1-\mathrm{H}, \mathrm{d}, \mathrm{J}=7.5 \mathrm{~Hz}$ and $\delta 5.3(1-\mathrm{H}, \mathrm{brs})$ attributed to two anomeric protons of D-glucose, Lrhamnose respectively, also presence of signal at $\delta 1.1 \mathrm{ppm}(3-\mathrm{H}, \mathrm{d}, \mathrm{J}=6 \mathrm{~Hz})$ is due to methyl group of L-rhamnose while the remains of sugar signals appear at range 3.8-3.1 ppm and the presence of two doublets at $\delta 7.4$ and 6.3 with J-coupling $16 \mathrm{~Hz}$ are assigned to $\alpha$ and $\beta$ olefinic

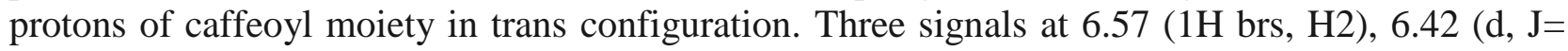
$2.8 \mathrm{~Hz}, \mathrm{H} 5), 6.4$ (dd, J=2.8 Hz, H6) suggested 3, 4 dihydroxy phenyl ethanoid moiety, also signal at $2.64(2 \mathrm{H}, \mathrm{t}, \mathrm{J}=7 \mathrm{~Hz})$ which is attributed to proton at $\mathrm{B}-\mathrm{C}$ of phenylethanoid moiety while the caffeoyl unit was found to be located at $\mathrm{C}$ - 4 of the glucose moiety due to strong deshielding of $\mathrm{H}$ 4- glucose resonance at 4.9 (1-H-t-like).

${ }^{13} \mathrm{C}-\mathrm{NMR}$ Spectrum showed two signals at $\delta 104.2$ and 103.0 which assigned to two anomeric carbon of D-glucose, L-rhamnose which confirmed by presence of signal at $\delta 62.4$ due to C-6 of glucose and at $\delta 18.47 \mathrm{ppm}$ which is attributed to methyl group of L-rhamnose, while signals at 36.59 and 72.4 are assigned to $\alpha, \beta$ carbons of phenylethanoid moiety. The interglycosidic linkage was confirmed to be $\alpha$-L-rhamnosyl-(1-3- $\beta$-D-glucoside on the basis of the strong $\alpha$-down field effect of C-3 glucose carbon at $81.66(\sim \Delta-4.5 \mathrm{ppm})$ in the ${ }^{13} \mathrm{C}-\mathrm{NMR}$ spectrum.

Finally, ${ }^{4} \mathrm{C}_{1}$ and ${ }^{1} \mathrm{C}_{4}$ - pyranoses of glucoside and rhamnosyl moieties were established on the basis of $\mathbf{J}$ values of vicinal coupled protons especially that of $\mathrm{J}_{1,2}$ and $\delta \mathrm{C}$ - values of sugar moieties.

Thus compound 3 was identified as acetoside $\left(\beta-\left(3,4\right.\right.$ dihydroxyphenyl-ethyl-O- $\alpha-L-{ }^{1} C_{4^{-}}$ rhamnopyranosyl (1-3)- $\beta$-D-(4-O-caffeoyl ${ }^{4} C_{1}$ glucopyranoside, figure; 1.

\section{Compound 4:}

Yellowish amorphous powder weighing $40 \mathrm{mg}$ having m.p. 271-273 ${ }^{\circ} \mathrm{C}$ gave positive Molisch's test which on PC investigation yielded one spot with $R_{f}$ values 0.53 and 0.42 in solvent systems $S_{1}$ and $S_{2}$ respectively, the compound gave dark purple fluorescent under UV light which turned to yellow on exposure to ammonia vapors or spraying with aluminum chloride reagent. The colour reaction and $\mathrm{R}_{\mathrm{f}}$ values gained in the range of $\mathrm{C}$ - diglycoside (Agrawal 1989 and Harborne et al, 1982), acid hydrolysis of the compound showed no effect which is characteristic to Cglycoside while, hydrolytic cleavage using hydroiodic acid in phenol yielded apigenin as aglycone and glucose as the only sugar moiety.

UV spectral data in methanol showed $\lambda_{\max } \mathrm{nm} 332,272$ characteristic of flavone where a bathochromic shift $(+58 \mathrm{~nm})$ on addition of sodium methoxide with increase in intensity indicating 4 hydroxyl is free, also bathochromic shift in occurred in band II with sodium acetate $(+\Delta 7 \mathrm{~nm})$ suggesting that 7 hydroxyl group is free and a bathochromic shift $(+\Delta 52 \mathrm{~nm})$ on addition of aluminum chloride indicating that the five position is located as free hydroxyl group.

${ }^{1} \mathrm{H}-\mathrm{NMR}$ Spectral data (DMSO- $d_{6} \delta \mathrm{ppm}$ ) showed the absence of H-6, H-8 which indicate glycosidation occur in both position that confirmed by presence of two anomeric protons at $\delta \mathrm{ppm}$ 4.75, $4.82(\mathrm{~d}, \mathrm{~J}=8 \mathrm{~Hz})$ which is characteristic of C- glycosidation (Agrawal 1989 and Markham 1982).

${ }^{13} \mathrm{C}$ - NMR showed $\mathrm{C}_{6}$ and $\mathrm{C}_{8}$ at $\delta$ ppm $107.5,105.3$ proving the glycosidation on both position. Also presence of two signal at 74.1, 73.39 of two anomeric carbons of C-1" and C1 "' are also characteristic of C- glucoside (Agrawal 1989) while -ve ESI-MS spectrum showed its molecular ion peak at m/z 593 corresponding to M.wt. 594 of di-hexoside structure which confirm 
C-type glycoside linkage (Waridel et al., 2001), this evidence was further re-confirmed by 2 DNMR (HMQC) which showed coherence between $\mathrm{H}-1$ " at $4.7 \mathrm{ppm}$ and C-1" at 74.1, H-1" 'at 4.8 and $\mathrm{C}-1{ }^{\prime \prime}$ at 73.39 .

From both chromatographic behavior and spectral data mentioned, compound 4 was identified as 6, 8-C- $\beta-D-{ }^{4} C_{1}$ glucopyranosyl-apigenin (Vicenin II), figure, 1 and tables 1-3.

\section{Compound 5:}

Yellowish amorphous powder weighing $40 \mathrm{mg}$ having m.p. $171-174{ }^{\circ} \mathrm{C}$ gave positive Molisch's test, $\mathrm{PC}$ investigation yielded one spot with $\mathrm{R}_{\mathrm{f}}$ values 0.38 and 0.15 in solvent systems $S_{1}$ and $S_{2}$ respectively, the compound gave dark purple fluorescent under UV light which turned to yellow on exposure to ammonia vapors or spraying with aluminum chloride reagent. The compound also showed greenish blue when treated with ferric chloride reagent, this chromatographic behavior indicates of flavonoid glycoside nature (Cheng et al., 1976).

Acid hydrolysis yielded 3-methoxy apigenin (chrysoeriol) and glucose as single sugar moiety while UV spectral analysis in methanol showed bands $(335,301,265,254)$ indicate flavone nature (Mabry et al, 1970), it gave bathochromic shift in band I ( $+\Delta 52 \mathrm{~nm})$ with increase in intensity by addition of sodium methoxide, while, with the addition of sodium acetate the bathochromic shift prove occupation of 7-hydroxyl position.

${ }^{1} \mathrm{H}-\mathrm{NMR}$ showed the presence of H-6 and H-8 appear downfield shifted proving seven position glucosidation, the anomeric sugar proton at $5.06 \mathrm{ppm}$ doublet with $\mathrm{J}$ value $7.8 \mathrm{~Hz}$ and remaining sugar proton appears at 3-3.7 ppm. Moreover, ${ }^{13} \mathrm{C}-\mathrm{NMR}$ confirmed the structure due to presence of $\mathrm{C}_{7}$ at $\delta 163.0$ upfield shifted and downfield shift of $\mathrm{C}_{6}$ and $\mathrm{C}_{8}$ by about $10 \mathrm{ppm}$, in addition to the assignment of characteristic six ${ }^{13} \mathrm{C}$ resonance of $O-\beta-D-{ }^{4} C_{1}$ glucopyranoside moiety in which $\mathrm{C}-1^{\prime \prime}$ at $\delta 100.0$, in addition to signal at 61.25 indicate methoxyl group, methoxylation of C-3 ' proved by $\alpha$ downfield shift of C-3 to 148.0 and $\beta$ upfield of C-4` at 150.1 ppm while downfield shift of H-2 at $7.41 \mathrm{ppm}$ and H-6 dd appear at $7.45 \mathrm{ppm}$.

These assignments of spectral data of compound 5 were confirmed by comparing with reported data of chrysoeriol-7-O- $\beta$-D-glucoside (Calis and Kirmizibekmez 2004) and accordingly it was identified as chrysoeriol-7-O- $\beta-D-{ }^{4} C_{1}$ gluco-pyranoside $(5,7,4$ trihydroxy, 3 methoxy flavone-7-O- $\beta-\mathrm{D}-{ }^{4} \mathrm{C}_{1}$ glucopyranoside)

figure, 1 and tables 1-3

\section{Compound 6:}

Pale yellowish amorphous powder weighing $40 \mathrm{mg}$ having m.p. $187-189^{\circ} \mathrm{C}$ gave positive Molisch's test, $\mathrm{PC}$ investigation yielded one spot with $\mathrm{R}_{\mathrm{f}}$ values 0.44 and 0.16 in solvent systems $S_{1}$ and $S_{2}$ respectively, the compound gave dark purple fluorescent under UV light at $365 \mathrm{~nm}$ which turned to yellow on exposure to ammonia vapors or spraying with aluminum chloride reagent. The compound also showed greenish blue when treated with ferric chloride reagent, this chromatographic and chemical behavior indicates of flavonoid glycoside nature (Cheng $\boldsymbol{e t}$ al., 1976).

Acid hydrolysis yielded luteolin aglycone and glucose as single sugar moiety.

UV spectral analysis in methanol showed bands $(255,267,347)$ indicate flavone nature gave a bathochromic shift in band I $(+\Delta 46 \mathrm{~nm})$ with increase in intensity by adding sodium methoxide and on addition of sodium acetate which prove occupation of 7-hydroxyl position, also, a bathochromic shift in band I (+24 nm) occurred on using boric acid which prove the presence of orthodihydroxy group. 
Moreover, another bathochromic shift in band $\mathrm{I}(+\Delta 59 \mathrm{~nm})$ occurred on adding aluminum chloride reagent confirmed the existence of 3`, 4 ' dihydroxy form and that the 5 hydroxyl position is free.

${ }^{1} \mathrm{H}-\mathrm{NMR}$ showed the presence of doublet at $\delta 6.9 \mathrm{ppm} \mathrm{d}, \mathrm{J}=8 \mathrm{~Hz}, \mathrm{H}-5$; at 7.4 (dd J $\simeq 2 \mathrm{~Hz}$, $\mathrm{J} \simeq 8 \mathrm{~Hz}) \mathrm{H}-6$ ', H-2', this confirming the existence of $3^{\prime}$, 4'hydroxyl in B ring while $\mathrm{H}-6, \mathrm{H}-8$ appears downfield shifted proving seven position occupation. The anomeric sugar proton $\mathrm{H}_{1}{ }^{\prime \prime}$ appeared at $\delta 5.1 \mathrm{ppm} \mathrm{d}, \mathrm{J}=8 \mathrm{~Hz}$ while the remaining sugar protons appeared at $\delta 3.7-3.2 \mathrm{ppm}$.

${ }^{13} \mathrm{C}-\mathrm{NMR}$ spectrum also confirmed the structure due to the presence of $\mathrm{C}_{7}$ at $\delta 163 \mathrm{~nm}$ up field shifted and downfield shift of $\mathrm{C}_{6}$ and $\mathrm{C}_{8}$ by about $10 \mathrm{ppm}$, also, the assignment of characteristic six ${ }^{13} \mathrm{C}$-resonance of an extra $O-\beta-{ }^{4} \mathrm{C}_{1}$ glucopyranoside moiety where $\mathrm{C}_{1}{ }^{\prime \prime}$ appeared at $100.4 \mathrm{ppm}$.

Accordingly, compound 6 was identified as Luteolin-7-O- $\beta-D-{ }^{4} C_{1}$ glucopyranoside, figure, 1 and tables 1-3 (Harborne et al, 1975 and Geissman 1968).

\section{Compound 7:}

Pale yellowish amorphous powder weighing $35 \mathrm{mg}$ having m.p. $181-183{ }^{\circ} \mathrm{C}$ gave positive Molisch's test, $\mathrm{PC}$ investigation yielded one spot with $\mathrm{R}_{\mathrm{f}}$ values 0.43 and 0.18 in solvent systems $S_{1}$ and $S_{2}$ respectively, the compound gave dark purple fluorescent under UV light at $365 \mathrm{~nm}$ which turned to yellow on exposure to ammonia vapors or spraying with aluminum chloride reagent. The compound also showed greenish blue when treated with ferric chloride reagent, this chromatographic behavior indicates of flavonoid glycoside nature (Cheng et al, 1976).

Acid hydrolysis yielded luteolin aglycone and arabinose as single sugar moiety.

UV spectral data in methanol showed two main bands at $\lambda_{\max } 345$ (band I) 253 (band II) and $264(\mathrm{sh}) \mathrm{nm}$ while when treated with sodium methoxide gave a bathochromic shift without decrease intensity $(\Delta \lambda=+53 \mathrm{~nm})$ in band I, thus proving 4 - hydroxyl group to be free and on treatment with sodium acetate gave a bathochromic shift in band II $(\Delta \lambda=+14 \mathrm{~nm})$, indicating the presence of free hydroxyl group at $\mathrm{C}_{7}$ when using sodium acetate and boric acid gave a bathochromic shift in band I $(\Delta \lambda=+27 \mathrm{~nm})$, indicating the presence of two catecholic hydroxyl group and aluminum chloride gave a bathochromic shift in band I $(\Delta \lambda=+80 \mathrm{~nm})$, indicating 3', 4 and 5 hydroxyl position are free and finally aluminum chloride and hydrochloric acid gave a hypthochromic shift in band I $(\Delta \lambda=+40 \mathrm{~nm})$ with reference to band I in aluminum chloride alone indicating the presence of 3',4 dihydroxy system.

Negative ESI/MS exhibited molecular ion peak at 417 while ${ }^{1} \mathrm{H}-\mathrm{NMR}$ (DMSO- $d_{6}$ ) (Fig. 46) $\delta$ ppm showed two doublet signals at $\delta 6.42$ and 6.19 ppm for H-8 and H-6 respectively, doublet of doublet (dd) signals at $\delta 7.4 \mathrm{ppm}(\mathrm{J}=2.5 \mathrm{~Hz})$ for $\mathrm{H}-6$, doublet signals at $\delta 7.38 \mathrm{ppm}$ $(\mathrm{J}=8 \mathrm{~Hz})$ for $\mathrm{H}-2{ }^{`}$, doublet signals at $\delta 6.84 \mathrm{ppm}(\mathrm{J}=8 \mathrm{~Hz})$ for $\mathrm{H}-5^{`}$ and singlet signal at $\delta 6.64$ for $\mathrm{H}-3$ confirming that the compound of flavone type and the anomeric proton of arabinose (H-1") appeared at $5.13 \mathrm{ppm}(\mathrm{d}, \mathrm{J}=6.9 \mathrm{~Hz})$, which confermed by anomeric carbon atome at $100.7 \mathrm{ppm}$

${ }^{13} \mathrm{C}-\mathrm{NMR}$ spectrum also confirmed the structure due to the presence of $\mathrm{C}_{7}$ at $\delta 163 \mathrm{~nm}$ up field shifted and downfield shift of $\mathrm{C}_{6}$ and $\mathrm{C}_{8}$ by about $10 \mathrm{ppm}$, also, the assignment of characteristic six ${ }^{13} \mathrm{C}$-resonance of an extra $\boldsymbol{O}-\beta-D-{ }^{4} C_{I}$-arabinoside moiety .

Compound 7 was finally identified as Luteolin $-7-O-\beta-D-{ }^{4} C_{1}$-arabinoside, figure, 1 and tables 1-3 (Agrawal 1989).

\section{Compound 8:}

Pale yellowish amorphous powder weighing $1.7 \mathrm{~g}$ having m.p. $314{ }^{\circ} \mathrm{C}$ gave positive Molisch's test, $\mathrm{PC}$ investigation yielded one spot with $\mathrm{R}_{\mathrm{f}}$ values 0.68 and 0.71 in solvent systems $S_{1}$ and $S_{2}$ respectively, the compound gave dark purple fluorescent under UV light at $365 \mathrm{~nm}$ 
which turned to yellow on exposure to ammonia vapors or spraying with aluminum chloride reagent. The compound also showed greenish blue when treated with ferric chloride reagent; this chromatographic behavior indicates flavonoid glycoside nature (Cheng et al, 1976).

Acid hydrolysis yielded quercetin aglycone and L-rhamnose as sugar moiety where both were identified using CoPC while negative ESI/MS spectrum showed molecular ion peak at $\mathrm{m} / \mathrm{z}$ 447.039(M-H) ${ }^{-}$corresponding to molecular weight of 448 (Harborne et al, 1975 and Geissman 1968).

${ }^{1} \mathrm{H}-\mathrm{NMR}$ spectrum showed the characteristic five ${ }^{1} \mathrm{H}$ - resonances of two spin coupling system for quercetin 3-O-glycoside structure were assigned to $\mathrm{H}-2$, $\mathrm{H}-6, \mathrm{H}-5^{\prime}\left(1^{\text {st }}\right), \mathrm{H}-8$ and H-6 $\left(2^{\text {nd }}\right)$ while sugar moiety showed signals at $\delta 5.26$ ( $\alpha$-anomeric proton as brs) 3.98 (brs of $\left.\mathrm{H}-2^{\prime \prime}\right)$ and $0.83 \mathrm{ppm}$ (for $\mathrm{CH}_{3}-6^{\prime \prime}$ ) characteristic for $\boldsymbol{\alpha}$-L-rhamnopyranoside moiety at $\mathrm{OH}-3$.

${ }^{13} \mathrm{C}$-NMR showed typical $15{ }^{13} \mathrm{C}$-resonance for a quercetin moiety, among them $\mathrm{C}-4$ and C-3` at 148.80 and 145.56 as a key signals of 3`, 4`dihydroxy B-ring in all quercetin glycosides, it showed six ${ }^{13} \mathrm{C}$-resonances of an $\boldsymbol{O}$-rhamnopyranoside moiety, also C-4", C-3", C-2"and C-5"of $\delta$ values around $70 \mathrm{ppm}$ and $\mathrm{CH}_{3}-6$ " which is the most up field signal at 18.11 indicating glycosidation at OH-3 which was proved by the relative up field shift of C-3 to134.58 ( $\Delta \simeq 3-4$ PPM) and down field shift of C-2 relative to those of the aglycone (Geissman 1962), moreover, all other ${ }^{13} \mathrm{C}$ resonances were proved by comparison with reported data of related compounds.So, compound 8 was identified as Quercetin -3-O- $\alpha-L^{1} C_{4}$-rhamno-pyranoside (Quercetrin) figure, 1 and tables 1-3 (Agrawal 1989, Harborne et al, 1975 and Mabry et al, 1970) .

\section{Compound 9:}

Pale yellowish crystalline powder weighing $35 \mathrm{mg}$ soluble in mixture of chloroform and methanol having m.p. 345-346 ${ }^{\circ} \mathrm{C}$ gave negative Molisch's test and positive magnesium in concentrated hydrochloric acid test, it has yellow colour under UV $365 \mathrm{~nm}$ changed to intensive yellow after spraying with $2 \%$ aluminum chloride reagent this behavior indicates that it is of flavonoid aglycone nature.

Mass spectrum showed molecular ion peaks at m/z (55):271 $\left(\mathrm{M}^{+}\right)(62), 247(7), 153(9)$ and 125(100) while UV spectrum showed two major absorption bands in methanol at 267 and 336, typical for flavonoid, the addition of sodium methoxide gave stable bathochromic shift thus indicating that 4 position to be free hydroxyl while the addition of sodium acetate exhibits a bathochromic shift so proving that 7 position to be free hydroxyl, addition of sodium acetate and boric acid gave no shift so proving the absence of catecholic hydroxyls while addition of aluminum chloride gave a shift of $(\Delta+47) \mathrm{nm}$ which was not changed after addition of dilute hydrochloric acid, so further confirming the absence of catecholic hydroxyls.

${ }^{1} \mathrm{H}-\mathrm{NMR}$ showed apigenin type protons as followe; two doublets at $\delta 6.3$ and 6.45 with $\mathrm{J}=$ $2.5 \mathrm{~Hz}$ for H-8 and H-6 respectively and two doublets at $\delta 6.92$ and 7.85 with $\mathrm{J}=8 \mathrm{~Hz}$ for H-3', H$5^{\prime}$ and H-2', H-6' and singlet at 6.59 for $\mathrm{H}-3$ while ${ }^{13} \mathrm{C}-\mathrm{NMR}$ indicated the presence of 15 carbon atoms which was found to be agreeable with reported data about apigenin figure, 1 and tables 1-3 (Mabry et al, 1970).

\section{Compound 10:}

Yellowish amorphous powder weighing $50 \mathrm{mg}$ soluble in mixture of chloroform and methanol, with m.p. $236^{\circ} \mathrm{C}$ gave negative Molisch's test and positive magnesium in concentrated hydrochloric acid test, it has yellow colour under UV $365 \mathrm{~nm}$ changed to intensive yellow after spraying with $2 \%$ aluminum chloride reagent this behavior indicates that it is of flavonoid aglycone nature. It gave one spot on $\mathrm{PC}$ with $\mathrm{R}_{\mathrm{f}}$ values 0.78 and 0.05 using in solvent systems $\mathrm{S}_{1}$ and $\mathrm{S}_{2}$ respectively. 
UV spectral data in methanol showed two main bands at $\lambda_{\max } 345$ (band I) 253 (band II) and $264(\mathrm{sh}) \mathrm{nm}$, the addition of sodium methoxide gave a bathochromic shift without decrease intensity $(\Delta \lambda=+53 \mathrm{~nm})$ in band I, thus proving 4'- hydroxyl group to be free while the addition of sodium acetate gave a bathochromic shift in band II $(\Delta \lambda=+14 \mathrm{~nm})$, indicating the presence of free hydroxyl group at $\mathrm{C}_{7}$, addition of sodium acetate and boric acid gave a bathochromic shift in band I $(\Delta \lambda=+27 \mathrm{~nm})$, indicating the presence of two catechol hydroxyl group while the addition of aluminum chloride gave a bathochromic shift in band $\mathrm{I}(\Delta \lambda=+80 \mathrm{~nm})$, indicating $3^{`}$, 4 and 5 hydroxyl position are free which changed to hypthochromic shift on addition of hydrochloric acid in band $\mathrm{I}(\Delta \lambda=+40 \mathrm{~nm})$ with reference to band $\mathrm{I}$ in aluminum chloride alone indicating the presence of 3', 4'dihydroxy system.

${ }^{1} \mathrm{H}-\mathrm{NMR}$ (DMSO- $d_{6}$ ) (Fig. 46) $\delta$ ppm showed two doublet signals at $\delta 6.42$ and $6.19 \mathrm{ppm}$ for H-8 and H-6 respectively, doublet of doublet (dd) signals at $\delta 7.4 \mathrm{ppm}(\mathrm{J}=2.5 \mathrm{~Hz})$ for $\mathrm{H}-6$, doublet signals at $\delta 7.38 \mathrm{ppm}(\mathrm{J}=8 \mathrm{~Hz})$ for $\mathrm{H}-2$ and doublet signals at $\delta 6.84 \mathrm{ppm}(\mathrm{J}=8 \mathrm{~Hz})$ for H5 proving luteolin- type and singlet signal at $\delta 6.64$ for $\mathrm{H}-3$ confirming that the compound 10 to be flavone in nature.

The structure was confirmed by ${ }^{13} \mathrm{C}-\mathrm{NMR}$ where all ${ }^{13} \mathrm{C}$ resonance was compared with reported data.

From all the previous data compound 10 was identified as 5, 7, 3', 4tetrahydroxy-flavone (Luteolin) figure, 1 and tables 1-3 (Agrawal 1989).

\section{Compound 11:}

Dark yellow amorphous powder weighing $45 \mathrm{mg}$ soluble in mixture of chloroform and methanol with mp $312^{\circ} \mathrm{C}$ gaves negative Molisch's test and positive magnesium in concentrated hydrochloric acid test, it has yellow colour under UV $365 \mathrm{~nm}$ changed to intensive yellow after spraying with $2 \%$ aluminum chloride reagent this behavior indicates that it is of flavonoid aglycone nature. It gave one spot on $\mathrm{PC}$ with $\mathrm{R}_{\mathrm{f}}$ values 0.75 and 0.03 using in solvent systems $\mathrm{S}_{1}$ and $S_{2}$ respectively.

EI-MS spectrum of compound 11 showed a molecular ion peak at $\mathrm{m} / \mathrm{z} 301$ corresponding to Mwt. 302 while UV spectral data, showed large bathochromic shift in band I with aluminum chloride reagent which disappear on addition of hydrochloric acid that is an evidence of orthodihydroxy B ring (Mabry et al, 1970).

${ }^{1} \mathrm{H}-\mathrm{NMR}$ spectrum showed an ABX coupling system of three proton signals as meta doublet (H-2'), ortho-meta dd (H-6') and ortho doublet (H-5') for 3`, $4^{\prime}$ dihydroxy B-ring and AM-spin coupling system of two meta coupled protons at $6.38,6.18$ assigned $\mathrm{H}-8$ and H-6 respectively while ${ }^{13} \mathrm{C}$-NMR spectral data $\delta$ ppm exhibited fifteen typical carbon resonances for quercetin moiety were assigned in the aromatic region, showed two key signals of quercetin aglycone were assigned at 149.15 (C-4') and 145.49 (C-3`) ppm.

Accordingly, compound 11 was identified as 3, 5, 7, 3, 4, pentahydroxy -flavone (quercetin) figure, 1 and tables 1-3 (Agrawal 1989 and Harborne et al, 1975).

This is the first time for isolation of all compounds except acetoside from Russelia equisetiformis.

\section{Biological studies:}

Determination of median lethal dose $\left(\mathbf{L D}_{\mathbf{5 0}}\right)$; the gained results revealed that the investigated methanol extract was non-toxic up to $3.4 \mathrm{~g} / \mathrm{Kg}$ which agree the reported data (Kolawole et al, 2006).

Antidepressant effect; Study of the antidepressant effect of $n$-butanol and water extracts as well as the crude phenylethanoid fraction of Russelia equisetiformis at the dose of $300 \mathrm{mg} / \mathrm{Kg}$ using 
FST revealed that all of them reduced the duration of immobility, resulting in a $79.38 \%, 70.81 \%$, $71.04 \%$ and $73.8 \%$ immobility reduction compared with the control group, respectively compared to fluoxetine table, 4 .

Hepatoprotective effect; Carbon tetrachloride was found to induce hepatotoxicity by producing a wide array of dysfunctions, its hepatotoxicity illustrated by several mechanisms i.e. it reduces by cytochrome p- 450, a terminal oxidase in endoplasmic reticulum of liver followed by formation of trichloromethyl radical as metabolite of carbon tetrachloride then it reacts with molecular oxygen to form more electrophilic reactive radical which initiates lipid peroxidation of endoplasmic reticulum (Recknagel and Glende 1973).

Products of lipid peroxidation may cause damage to the biological membranes leading to serious cellular injury and leakage of serum marker enzymes from cytoplasm into the blood after rupture of plasma membrane like AST, ALT, ALP (Agrrwal and Mehendale 1983) and finally cell death (kim et al, 1990).

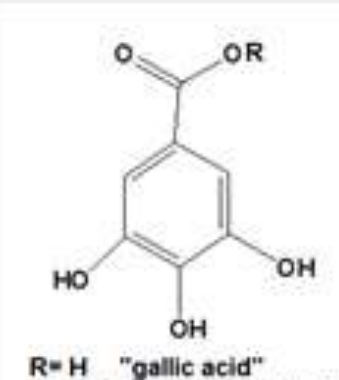

$\mathrm{R}=\mathrm{OCH}^{3}$ " Methyl gallate"

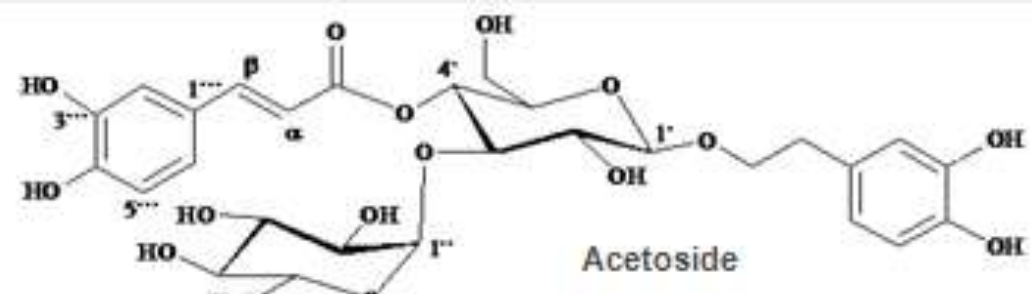

Acetoside<smiles></smiles>

Chrysoeriol-7-O-B-D- ${ }^{4} C_{1}$ glucopyranoside<smiles>[R6]c1cc(O)c2c(=O)cc(-c3ccc(O)c(O)c3)oc2c1</smiles>

$\mathrm{R}=\mathrm{H}$ "Luteolin" $\mathrm{R}=\mathrm{B}-\mathrm{D}$ - glucose

"Luteolin-7-O-B-D-4 $\mathrm{C}_{1}$ glucopyranoside"

$\mathrm{R}=\mathrm{B}-\mathrm{D}$-arabinose "Luteolin-7-O-B-D-4 Ctarabinoside"<smiles>O=c1cc(-c2ccc(O)cc2)oc2cc(O)cc(O)c12</smiles>

Apigenin<smiles>[R]Oc1c(-c2ccc(O)c(O)c2)oc2cc(O)cc(O)c2c1=O</smiles>

$\mathrm{R}=\mathrm{H}$ "Quercetin" $R=\alpha-L-$ rhamnose "Quercetin-3-O- $\alpha-L^{3} \mathrm{C}_{4}-$ rhamnopyranoside (Quercetrin)

Figure, 1: Compounds isolated from Russelia equisetiformis (Scrophelariaceae) cultivated in Egypt:

Three consecutive doses of carbon tetrachloride cause elevation in the serum ALT, AST, ALP, total bilirubin and induced damage to $\mathrm{Ca}^{2+}$ regulating system which leads to elevated cytoplasmic calcium concentration in mice hepatocytes which precedes the release of AST into the medium (Recknagel et al, 1977). 
Administration of methanol extract of Russelia equisetiformis reduces the elevation in serum levels of transaminases ALT and ALP which can maintain the functional integrity of hepatic cells and indicate its hepatoprotective effect, table 5.

Bilirubin the main bile pigment that is formed from breakdown of heme in red blood cells The administration of methanol extract of Russelia equisetiformis significantly reduce the total serum bilirubin level when compared with that of carbon tetrachloride intoxicated group but less than normal suggesting the efficiency of the extract in clearing elevated serum bilirubin, table 5.

Table, 5: Effect of oral administration of Russelia equisetiformis methanol extract on serum AST, ALT, ALP, $\gamma$ GT and total bilirubin in normal and liver damaged rats:

\begin{tabular}{|l|c|c|c|c|c|}
\hline Group Parameter & $\begin{array}{c}\text { AST } \\
(\mathbf{I U} / \mathbf{m l})\end{array}$ & $\begin{array}{c}\text { ALT } \\
(\mathbf{I U} / \mathbf{m l})\end{array}$ & $\begin{array}{c}\text { ALP } \\
(\mathbf{I U} / \mathbf{L})\end{array}$ & $\begin{array}{c}\boldsymbol{\gamma} \text { GT } \\
(\mathbf{U} / \mathbf{L})\end{array}$ & $\begin{array}{c}\text { Total bilirubin } \\
(\mathbf{m g} / \mathbf{d l})\end{array}$ \\
\hline Control & $168 \pm 1.18$ & $75.8 \pm 2.03$ & $40.9 \pm 1.82$ & $9.8 \pm 1.2$ & $0.29 \pm 0.01$ \\
\hline $\mathbf{C C l}_{\mathbf{4}}$ only & $423 \pm 7.0$ & $220 \pm 5.5$ & $66.1 \pm 3.42$ & $19 \pm 1.9$ & $1.4 \pm 0.1$ \\
\hline Methanol extract & $370.8 \pm 5.5$ & $176.3 \pm 3.9$ & $50.5 \pm 3.2$ & $17.8 \pm 1.8$ & $0.9 \pm 0.03$ \\
\hline
\end{tabular}

Results tabulated are representing means \pm S.E.

Antioxidant enzymes are the defense systems against carbon tetrachloride injury or any toxicity include, superoxide dismutase enzymes (SOD) which catalyze the conversion of two superoxides into hydrogen peroxide and oxygen that is substantially less toxic than superoxide and catalase enzymes (CAT) degrade hydrogen peroxide to water and oxygen and finish the detoxification reaction started by SOD, the gained results revealed that oral administration of Russelia equisetiformis methanol extract cause significant elevation of both levels of SOD and CAT, table 6 (Bowen 2003).

Table, 6: Effect of oral administration of Russelia equisetiformis methanol extract on antioxidant enzymes in $\mathrm{RBC}_{\mathrm{S}}$ in normal and liver damaged rats.

\begin{tabular}{|l|c|c|}
\hline \multicolumn{1}{|c|}{ Parameter } & SOD $(\mathbf{U} / \mathbf{m l})$ & CAT $(\mathbf{U} / \mathbf{m l})$ \\
\hline Control & $293.60 \pm 11.90$ & $17850 \pm 820$ \\
\hline $\mathbf{C C l}_{\mathbf{4}}$ & $109.40 \pm 5.60$ & $10302 \pm 650$ \\
\hline Methanol extract & $162 \pm 15.90$ & $13112 \pm 650$ \\
\hline
\end{tabular}

Results tabulated are representing means \pm S.E.

Vitamin C displays antioxidant properties and considered as other defense mechanism due to electron donating properties to the a free radicals causing their neutralization resulting in reduction of their tissue destructive capacity.

Administration of Russelia equisetiformis methanol extract showed significant increase in percentage of vitamin $\mathrm{C}(84 \%)$ in liver damaged rats but not reach to normal level indicate its curative effect, table, 7 . 
Table, 7: Effect of oral administration of Russelia equisetiformis methanol extract on serum vitamin $\mathrm{C}$ in normal and liver damaged rats.

\begin{tabular}{|l|c|}
\hline Group Parameter & $\begin{array}{c}\text { Vit. C } \\
(\boldsymbol{\mu g} / \mathbf{m l})\end{array}$ \\
\hline Control & $2.5 \pm 0.08$ \\
\hline $\mathbf{C C l}_{\mathbf{4}}$ & $1.2 \pm 0.05$ \\
\hline Methanol extract & $2.1 \pm 0.04$ \\
\hline
\end{tabular}

Results tabulated are representing means \pm S.E.

Phytochemical investigation of Russelia equisetiformis revealed presence of flavonoids, phenolic acids and phenylethanoids to which this curative effect may be attributed to all or some of these constituents which have been reported to have free radical scavenging effect owing to their redox properties and to some extent could also be due to their metal chelation potential (Roginsky and Lissi 2003).

The gained results revealed that the habitat of the plants affects greatly its active constituents and consequently their biological effects as it was reported that Russelia equisetiformis cultivated in Nigeria devoid of any flavonoid content and contain triterpenes and sterols, which could be sources of free radicals after metabolism it is suspected that the free radical generated by its metabolism and so such free radicals accumulate and adversely affect liver function as indicated by an increase in the serum levels of liver enzymes (Kolawole and Kolawole 2010) in contrast to our results which revealed the existence of several phenolic compounds exhibiting an array of biological activities.

\section{Acknowledgments:}

The authors express their thanks to Dr. Doaa Mohamed Abdel Latif, Lecturer of Biochemistry and Dr. Hebtallah Ibrahim, Lecturer of Pharmacology, Faculty of Pharmacy, AlAzhar University for their help and guidance biological studies.

\section{REFRENCES:}

Abu-Mustafa, E. A.; Bedour M. S.; Boulos L.; Elgamal, M. H. A.; El-Mumajjed, D. T.; Fayez, M. B. E.,;Girgis, A. N. and Sallam, L. A. R. (1997): Constituents of local plants. XXIII, tests of 350 accessions in a phytochemical screening program of Egyptian Plants, J. Ass. Adv Agr Sci Afri 4:61- 76.

Agrawal, P.K. (1989) ; ${ }^{13} \mathrm{C}$ NMR of Flavonoids, Chapter 6, Elsevier, New York.

Agrrwal, A. and Mehendale, H. (1983); Possible nephrotoxic effect of carbon tetrabromide and its interaction with chlordecone, Toxicol. 26: 231.

Awe, E.O. and Makinde, J.M. (2009); The hair growth promoting effect of Russelia equisetiformis; Journal of Natural Products (2) 70-73.

Awe, E.O., Adeloye, A., Idowu, T., Olajide, O.A., Makinde, J., (2008): Anti-nociceptive effect of Russelia equisetiformis leave extracts: Identification of its active constituents, Phytomedicine, 15: 301-305.

Awe, E.O., Adeniyi, O.A., Olajide, O.A., Wahkeel, O.K., Abiodun, O.O., Makinde, J.M., (2004a): Studies on antibacterial properties at Russelia equisetiformis (Schlecht and Chan) Scrophulariacae, Sci. Focus 6, 131-133. 
Awe, E.O., Makinde, J.M., Olajide, O.A. and Wahkeel, O.K., (2004b): Evaluation of antiinflammatory and analgesic activity of Russelia equisetiformis, Inflammopharmacology, 12, 399-405.

Awe, E.O.; Banjoko, O.S. and Makinde, M.J. (2010): Free radical scavenging: a possible mechanism of action for antiinflammatory activity of Russelia equisetiformis (Scrophulariaceae), Inflammopharmacology, 18:179-185.

Awe, E.O.; Makinde, J.M.; Adeloye, O.A. and Banjoko, S.O. (2009): Membrane stabilizing activity of Russelia equisetiformis; J. of Nat. Prod., 2:03-09.

Awe, E.O.; Makinde, J.M.; Olajide, O.A. and Wakeel, O.K. (2006): Membrane stabilizing activity: a possible mechanism of action for anti-inflammatory and analgesic properties of Russelia equisetiformis, Int J Pharmacol 2:447-450.

Blonde, N.C. (1994): Assessment of $\mathrm{CCl}_{4^{-}}$induced cirrhosis mode for studies of nitrogen metabolism in chronic liver diseases; Ann. Nutr Metab.

Borsini, F. and Meli, A. (1988); Is the forced swimming test a situable model for revealing antidepressant activity?, Psychopharmacology, 94,147-160.

Bowen, R. (2003); Free Radical and Reactive Oxygen, Pharmacogn Rev. 2010 Jul-Dec; 4(8): $118-126$.

Briner, K. and Dodel, R.C. (1998); New approaches to rapid onset antidepress-ants. Curr. Pharm. Des. 4, 291 - 302.

Burns, D., Reynolds, W.F., Reese, P.B. and Enriquez, R.G.(2001): Phyto-chemical screening of Russelia equisetiformis, Maqgn Reson. Chem. 387, 488-493.

Burns, D.; Reynolds, W. F.; Buchanan, G.; Reese, P. B. and Enriquez, R. G. (2000): Assignment of ${ }^{1} \mathrm{H}$ and ${ }^{13} \mathrm{C}$ spectra and investigation of hindered side-chain rotation in lupeol derivatives, Magn Reson. Chem 387:488- 493.

Calis, I. and Kirmizibekmez, H. (2004); Glycosides from Phlomis lunariifolia, Phytochemistry, 65 (18)2619-2625.

Cheng, J.C., Ching, B.W. and Lung, C.L. (1976); Chrysoeriol 7-O-rhamnoside from Sedum formosanum, Phytochemistry 15: 1420.

Cohen, M.A. (1970): Measurement of Catalase Activity in Tissue extracts; Analytical Biochemistry 30: 34.

Denson, K.W. and Bowers, E.E. (1961); The determination of ascorbic acid in white blood cells, Clinical Science, 21, 157.

Doumas, B.T., Perry, B.W., Sasse, E.A. and Straumfjord, J.R. (1973); Standard-ization in bilirubin assays: evaluation of select methods and stability of bilirubin solutions, Clin. Chem., 19: 984.

Duman, R.S. (2004); Depression: A Case of Neuronal Life and Death?, Biol. Psychiatry 56: 140- 45.

El Hela, A.A., Ibrahim, M.T., Abdelhady, N.M. and Abu Elwafa, S.A. (2011): Pharmacognostical Studies of Russelia Equisetiformis (Scrophelariaceae) Cultivated In Egypt, Az. J. Pharm. Sci., 44: 267-283.

Feighner, J.P (1999); Clinical and Preclinical Overview of Nemifitide (INN 0835), a Novel Pentapeptide Antidepressant, J.Clin. Psychiatry, 60, 22: 18- 22. 
Geissman, T.A. (1962); The Chemistry of Flavonoids Compounds 126; Pergamon Press, London.

Harborne, J.B., Mabry, T.J. and Mabry, H. (1982): The Flavonoids: Advances in Research, Chapter 2, Chapman and Hall ltd, London.

Harborne, J.B.; Mabry, T.J. and Mabry, H. (1975): The Flavonoids, Chapman and Hall, London.

Hiermann, A. (1983); Die Untersuchung potentieller Wirkstoffe in Epilobium-Arten.1.

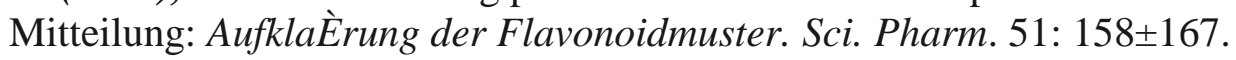

Johnson, C.E., Long-Ze, L., Harnly, J.M., Oladeinde, F.O., Kinyua, A.M. and Bronner, Y. (2011): Identification of the Phenolic Components of Vernonia amygdalina and Russelia equisetiformis, Journal of Natural Products, 4: 57-64.

Kerber, G.H.(1941); Pharmakologisch Methoden zur Auffindung von Arzneimittein und giften and analyze ihrer wirkungsweise.

Kim, H., Odend, H. and Bruchner, J. (1990); Effect of oral dosing vehicles on the acute hepatotoxicity of carbon tetrachloride in rats, Toxicol Appl Pharmacol, 102: 34-49.

Kochmar, J.F. and Moss, D.W. (1976); Fundamental of Clinical Chemistry NW Tietz (ed). WB Saunders Company Philadelphia, PA. P. 604.

Kolawale, O.T. and Kolawole, S.O. (2010): Effect of Russelia equisetiformis methanol and aqueous extracts on hepatic function indices, Biology and Medicine 2 (3): 38-41.

Kolawole, O.T. and Wakeel, O.K. (2006); Preliminary study on the toxicity of methanol extract of Russelia equisetiformis, Journal of Medical and Pharmaceutical Sciences, 2(3): 13.

Kolawole, O.T.; Makinde, J. M. and Olajide, O.A. (2007): Central Nervous System Depressant Activity of Russelia Equisetiformis, Nigerian Journal of Physiological Sciences, 22 (1-2): 59-63.

Lin, L. Z. and Harnly, J. (2007): A screening method for the identification of glycosylated flavonoids and other phenolic compounds using a standard analytical approach for all plant materials, J. Agric. Food Chem., 55: 1084-1096.

Lin, L. Z. and Harnly, J. (2008): Hydroxycinnamoylquinic acids of arnica flower and burdock roots using a standardized LC-DAD-ESI/MS profiling method. J. Agric. Food Chem.,56: 10105-10114.

Mabry, T.J., Markham, K.R and Thomas, M.B. (1970): The Systematic Identification of Flavonoids, Springer Verlag; New York.

Maltocks AR (1967): Detection of pyrrolizidine alkaloids on thin-layer chromate-grams, $J$ Chromatogr 27: 505-508.

Markham, K. (1982); Techniques of Flavonoid Identification, Academic Press, London.

Porsolt, R. D., Le Pichon, M, and Jalfre, M. (1977); Depression: a new animal model sensitive to antidepressant treatments, Nature, 266:730-2.

Quattrocchi, U. (2000); CRC World Dictionary of Plant Names, Common Names, Scientific Names, Eponyms, Synonyms and Etymology, Taylor \& Francis ISBN 978-0-84932678-3

Recknagel, R.O ., Glende, E.A. and Hruszkewycz, A.M. (1977); Free Radical in Biology Ed. Pryor W A, vol. III PP. 97, Academic Press New York. 
Roginsky, V. and Lissi, E.A. (2001); Review of methods to determine chain-breaking antioxidant activity in food, Food Chemistry, 92, 235-254

Stahl, E. (1969); Thin Layer Chromatography; $2^{\text {nd }}$ Edition Springer Verlag, Berlin, Heidelberg, New York.

Szasa, G. (1969): Serum $\gamma$ - Glutamyl transferase; Clin. Chem., 15: 124.

Tietz, N.W. (1976); Fundamentals of Clinical Chemistry $2^{\text {nd }}$ ed. WB Saunders company Philadelphia, London, Toronto.

Vines, G. (2004); Herbal harvests with a future: towards sustainable sources for medicinal plants, Plant life International; www.plantlife. org.uk

Waridel, P., Wolfender, J.L., Ndjoko, K., Hobby, K. R. , Major, H. J. and Hostettmannk, W. B. (2001); Evaluation of quadrupole time-of-flight tandem mass spectrometry and iontrap multiple-stage mass spectrometry for the differentiation of C-glycosidic flavonoids isomers, J. Chromatog. A, 926, 29-41.

Williams, M.G. (1983): Determination of superoxide dismutase; Research veterinary science, 34: 253.

Wollenweber, E.; Dörr, M.; Roitman, J.N. and Epicuticular, M. (2000): flavonoids of some Scrophulariaceae; Journal Zeitschrift für Naturforschung. Section C, Biosciences, 55 No. $1 / 2$ pp. $5-9$.

Yeager, T.H. and Gilman, F.E. (1991): Fertilizer Recommendations for Trees and Shrubs in Home and Commercial Landscapes, IFAS Publication CIR-948.

Young, D.S. (1975): Method of determination of amino transferases; Clin.chem. 21:5.

$$
\begin{aligned}
& \text { الفحص الكيميائى والبيولوجى لنبات النافورة ( الروساليا اكواستفورم) المنزرع فى مصر } \\
& \text { عاطف احمد عبد الحميد الحيلة* ، نيفين محمد عبد الهادي، ماجدة تهامي ابراهيم و سلوي ابو القاسم ابو الوفا }
\end{aligned}
$$

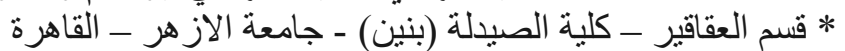

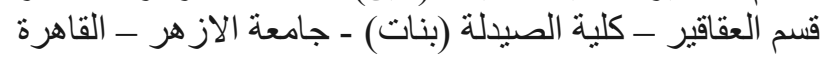

في هذا البحث تمكن الباحثون من فصل والتعرف على عشرة مركبات من المواد الفينولية و الفلافونبدية من الخلاصة

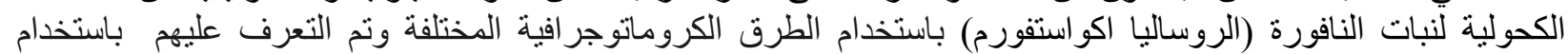

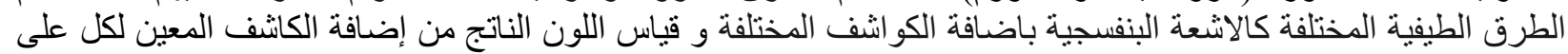

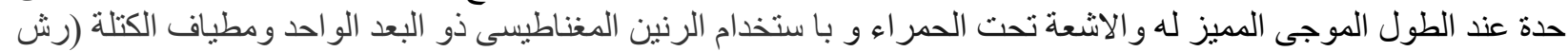

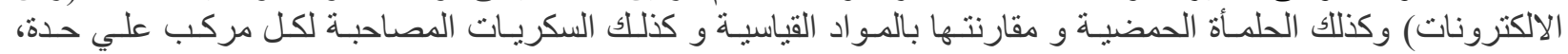
وكانت المركبات المفصولة كاكالاتى:

Gallic acid, methylgallate, vicenin II, chrysoeriol-7-O-B-D- ${ }^{4} \mathrm{C}_{1}$ glucopyranoside, luteolin 7-Oglucoside, luteolin-7-O- $\beta$-D- ${ }^{4} \mathrm{C}_{1}$-arabinoside, quercetrin, apigenin, luteolin and acetoside.

هذا وقد تم عمل در اسة بيولوجية لمستخلصات النبات المختلفة لدر اسة التاثير المضاد للاكتئاب و الو اقي لانسجة الكبد.

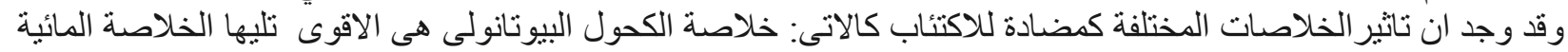

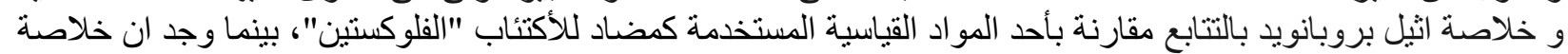

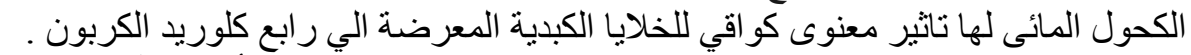

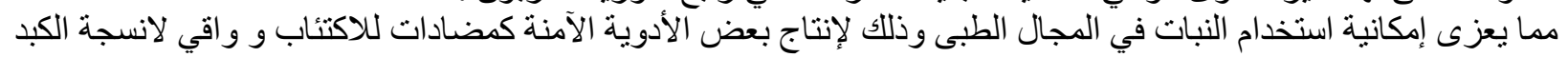
خاصة وان هذا النبات يمكن زر اعتة بكميات كبيرة. 